Brit. J. industr. Med., 1952, 9, 133.

\title{
URINARY COPROPORPHYRINS IN LEAD POISONING
}

\author{
BY
}

\author{
J. E. KENCH, R. E. LANE, and H. VARLEY \\ From the Nuffield Department of Occupational Health, University of Manchester, \\ and the Department of Clinical Pathology, Manchester Royal Infirmary
}

(RECEIVED FOR PUBLICATION DECEMBER 27, 1951)

Many aspects of haemopoiesis in lead poisoning remain obscure. When industrial plumbism was common the haemolytic action of lead was frequently described (Aub, Fairhall, Minot, and Reznikoff, 1925), although there were atypical features. The erythrocytes were somewhat deficient in haemoglobin, and faecal urobilinogen was not increased. Lead poisoning also differs from true haemolytic anaemia in the occurrence of coproporphyrin III in the urine (Grotepass, 1932; Fischer and Duesberg, 1932; Watson, 1936). It is coproporphyrin I which is excreted in haemolytic conditions characterized by hyperplasia of the bone marrow (Watson, 1937; Dobriner and Rhoads, 1938 ; Grinstein, Kamen, Wikoff, and Moore, 1950).

Rimington (1936) advanced the view that in enzymic synthesis of the porphyrins, in addition to type III porphyrin used in haemoglobin formation, a small amount of type I series is always produced, which, being of no value, is excreted. Urinary coproporphyrin I excretion therefore provided an index of the rate of haemopoiesis. Rimington (1938) further postulated that the coproporphyrin III excretion in lead poisoning is due to a partial blockage by lead of the entrance of iron into protoporphyrin 9 , thus interfering with haemoglobin formation (Fig. 1). He discounted the haemolytic action of lead, since faecal urobilinogen was normal; but recent isotopic studies by London, Shemin, and Rittenberg (1948) on the conversion in vivo of glycine $\mathbf{N}^{15}$ to stercobilinogen have shown that the latter is a very unreliable index of the rate of degradation of circulating haemoglobin. Kench, Gillam, and Lane (1942) found that excretion of coproporphyrin III was not sufficient by itself to account for the degree of haemoglobin deficit in this disease, and suggested that lead interfered all along the line of enzymatic syntheses, causing restricted formation of porphyrin and other intermediates.

D

\section{RIMINGTON'S ENZYMIC HYPOTHESIS.}

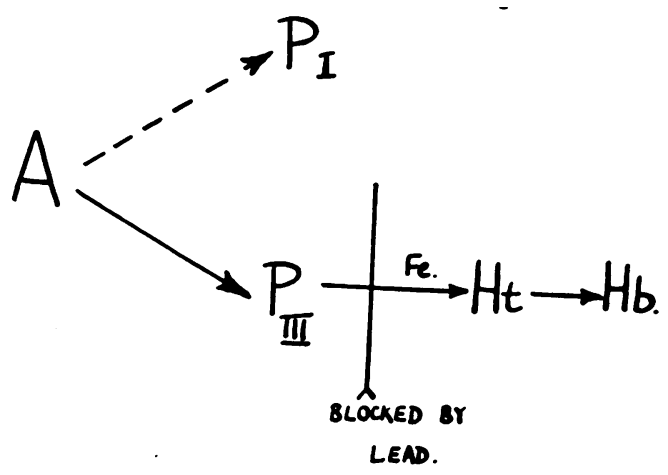

Fig. 1.-Rimington's enzymic hypothesis: $\mathbf{A}=$ pyrrole precursors. $P_{I}$ and $P_{I I I}=$ porphyrin series $I$ and III. $\mathbf{H t}=$ haem.

McFadzean and Davis (1949), by studying the effect of splenectomy in lead-poisoned rabbits, concluded that lead has a toxic action upon erythrocyte precursors in the bone marrow, producing defective haemoglobinization and persistence of basophilic substance in granular form, associated with an increased iron content. The stippled erythrocytes which arise from these precursors on entering the circulation are rapidly taken up by the spleen, producing a haemolytic type of anaemia, the severity of which varies with the intensity and duration of lead absorption.

In this paper we describe a study of the excretion of lead and porphyrins in the urine of seven bath enamellers immediately after considerable exposure to lead for three to six months. They were first seen in December, 1950, and had signs and symptoms of poisoning including anaemia, constipation, and in two cases severe abdominal colic. They were withdrawn from lead work immediately, but subsequently four of them did lead smelting without the knowledge of the works manager. 
We have observed that coproporphyrin III excretion in lead poisoning is accompanied by an increase in coproporphyrin I, which supports the conclusion of McFadzean and Davis that there is a haemolytic action in lead poisoning.

\section{Materials and Methods}

Haemoglobin was determined by the M.R.C. grey wedge photometer (MacFarlane, King, Wootton, and Gilchrist, 1948).

Punctate basophilia was counted under dark ground illumination (Lane, 1949).

Urinary lead was determined by a modified dithizone method (Kench, 1940) on specimens collected twice weekly.

Ether-soluble porphyrins were extracted by the usual acetic acid-ether procedure and measured fluorimetrically (Rimington, 1943). The urinary residue was shaken with alumina to adsorb uroporphyrins, with subsequent elution as methyl esters. Ether-soluble porphyrins extracted from the urine of all cases were pooled. The total quantity of urine was 46 litres collected over 130 days. These porphyrins were analysed by single dimensional chromatography by the method of Nicholas and Rimington (1949).

Chromatography of the derived methyl esters was performed as described by Chu, Green, and Chu (1951), with certain modifications. The solvents were purified as follows : oleic acid was distilled under $15 \mathrm{~mm} . \mathrm{Hg}$ pressure; n-propanol was fractionally distilled, b.p. 95-97 ${ }^{\circ} \mathrm{C}$; kerosene was filtered and distilled; main fraction b.p. $140-160^{\circ} \mathrm{C}$.

Whatman No. 1 filter paper was used without pretreatment. Single strip chromatograms were developed with oleic acid-kerosene $(1: 1)$, or with the mixtures chloroform-kerosene $(2.6: 4)$ and n-propanol-kerosene $(1: 5)$. Chloroform-kerosene, followed by n-propanolkerosene, was also used for two-dimensional separation.

The fluorescent areas on the paper were cut out with a glass microscope slide, and the porphyrin methyl esters extracted with $4 \mathrm{ml}$. chloroform (or $4 \mathrm{ml}$. $\mathrm{CHCl}_{3}+$ $1 \mathrm{ml}$. glacial acetic acid from two-dimensional chromatograms). Coproporphyrin III was diluted with chloroform until its fluorescence matched that of the coproporphyrin I solution. The positions of all spots were checked with authentic specimens of coproporphyrin I and III methyl esters, whose recovery from the chromatogram was complete, within the error of fluorescence measurement. Losses sustained by the coproporphyrin isomers in the methylation procedure were similar. Oleic acid-kerosene remaining on the paper, after allowing to drain for one minute, did not interfere with the measurement of porphyrin fluorescence, which was not quenched, and blue fluorescence was screened by the orange filter incorporated in the fluorimeter.

The urinary specimens, which were collected on the 329th and 330th days, were each examined by paper chromatography for separation of isomers.

Coproporphyrin methyl esters prepared from pooled ether-soluble porphyrins were separated by repeated rigorous extraction with cold, dry ether. The later ether washings carried away small quantities of coproporphyrin I, which were sacrificed to ensure that no trace of isomer III could remain. The crude insoluble material (7 mg.) was crystallized from methanol-chloro. form to give coproporphyrin I methyl ester m.p. $244^{\circ}$ C. (Fig. 2), whilst coproporphyrin III ester had m.p. $136^{\circ} \mathrm{C}$.

\section{Results}

Anaemia present at the outset of illness had been mainly resolved by the 120 th day. There was an average gain of $3.7 \mathrm{~g}$. haemoglobin per $100 \mathrm{ml}$. blood (Table 1).

At first punctate basophil counts ranged from 2,000 , to 13,000 per million R.B.C.s and gradually decreased,

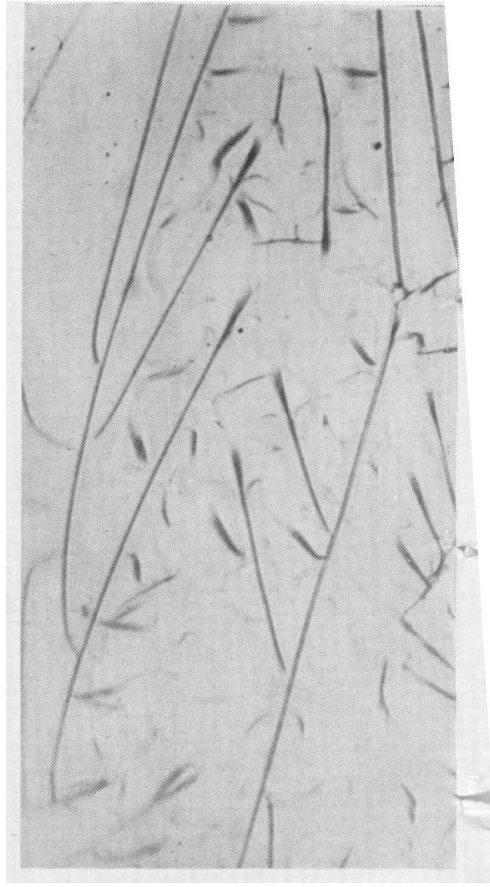

FIG. 2.-Photomicrograph of crystalline coproporphyrin I tetra-methyl ester isolated from urine in lead poisoning $\times 350$..

TABLE 1

HAEMOGLOBIN CONCENTRATION AND PUNCTATE BASOPHILIA IN LEAD POISONING

\begin{tabular}{|c|c|c|c|}
\hline $\begin{array}{l}\text { Case } \\
\text { No. }\end{array}$ & $\begin{array}{c}\text { Day of } \\
\text { Experi- } \\
\text { ment }\end{array}$ & $\begin{array}{c}\text { Haemoglobin } \\
\text { Concentration } \\
\text { (g. } / 100 \mathrm{ml} \text {. blood })\end{array}$ & $\begin{array}{c}\text { Punctate } \\
\text { Basophils (per } \\
\text { million R.B.C.) }\end{array}$ \\
\hline 1 & $\begin{array}{r}5 \\
110 \\
127\end{array}$ & $\begin{array}{r}9 \cdot 5 \\
14 \cdot 4 \\
13 \cdot 2\end{array}$ & $\begin{array}{l}12,000 \text { S.M. } \\
1,300 \mathrm{~S} . \\
1,000 \mathrm{~S} .\end{array}$ \\
\hline 2 & $\begin{array}{r}26 \\
70 \\
127\end{array}$ & $\begin{array}{r}9 \cdot 2 \\
15 \cdot 5 \\
14 \cdot 9\end{array}$ & $\begin{array}{l}\text { 10,000 S.M.L. } \\
\text { 7,200 S.M.L. } \\
\text { 2,200 S. }\end{array}$ \\
\hline 3 & $\begin{array}{r}5 \\
70 \\
120\end{array}$ & $\begin{array}{l}12 \cdot 4 \\
14 \cdot 3 \\
14 \cdot 9\end{array}$ & $\begin{array}{l}2,000 \text { S.M. } \\
2,100 \mathrm{~S} .\end{array}$ \\
\hline 4 & $\begin{array}{r}2 \\
120 \\
127\end{array}$ & $\begin{array}{l}12 \cdot 8 \\
14 \cdot 2 \\
14 \cdot 3\end{array}$ & $\begin{array}{l}\text { 4,000 S.M. } \\
2,400 \text { S. } \\
1,600 \text { S. }\end{array}$ \\
\hline 5 & $\begin{array}{r}2 \\
110 \\
127\end{array}$ & $\begin{array}{l}12 \cdot 4 \\
16 \cdot 2 \\
15 \cdot 5\end{array}$ & $\begin{array}{c}\text { 13,000 S.M.L. } \\
\text { 4,000 S.M. } \\
\text { 3,200 S.M.L. }\end{array}$ \\
\hline 6 & $\begin{array}{r}6 \\
60\end{array}$ & $\begin{array}{l}11 \cdot 9 \\
11 \cdot 0\end{array}$ & 3,500 S.M. \\
\hline 7 & $\begin{array}{r}1 \\
26 \\
70\end{array}$ & $\begin{array}{r}9 \cdot 2 \\
15 \cdot 5\end{array}$ & $\begin{array}{r}\text { 10,000 S.M.L. } \\
\text { 7,200 S.M.L. }\end{array}$ \\
\hline
\end{tabular}

S.M.L.-small, medium, large granules respectively. 


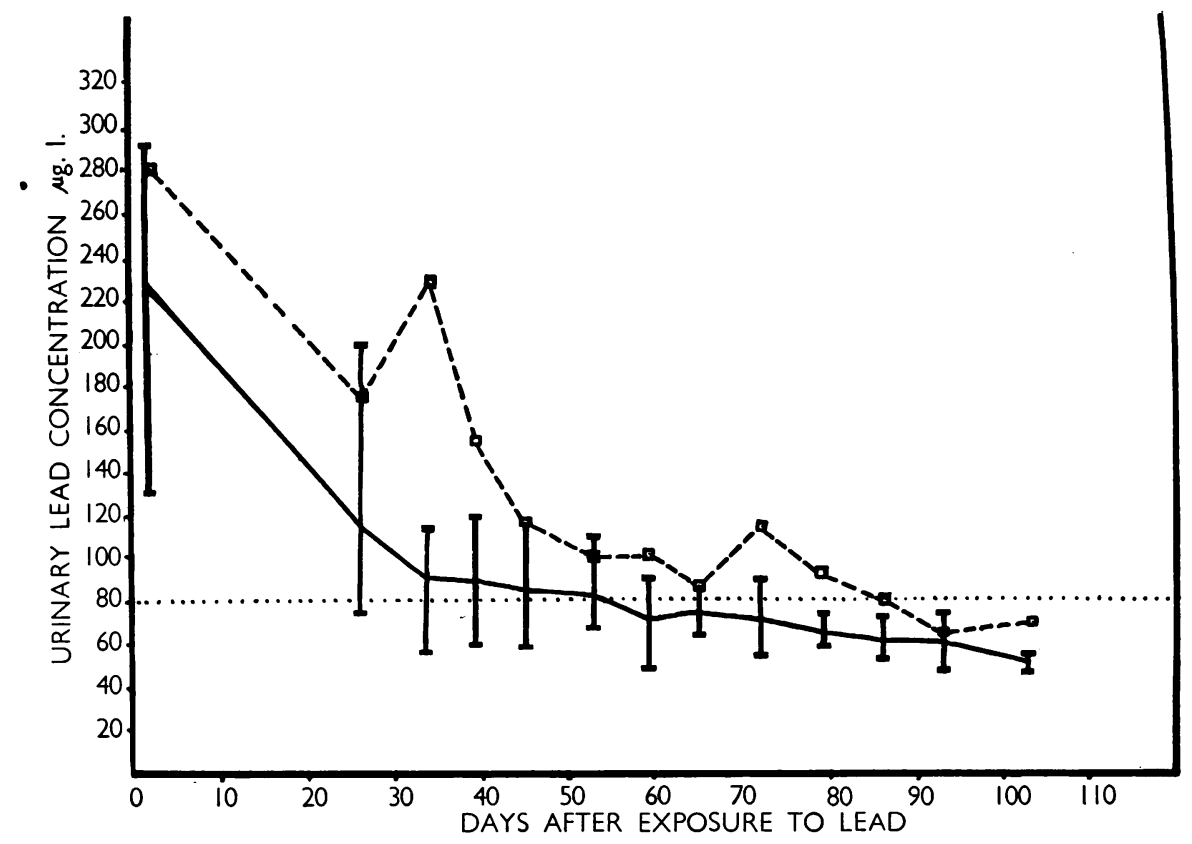

FIG. 3.-Graph illustrating changes in urinary lead in lead poisoning. The upper curve presents data for one workman with a history of protracted, heavy lead absorption (Case No. 4). The lower curve shows the mean values for the remaining six men. Vertical lines give the ranges of observations. The upper limit of normal is shown by the horizontal dotted line.

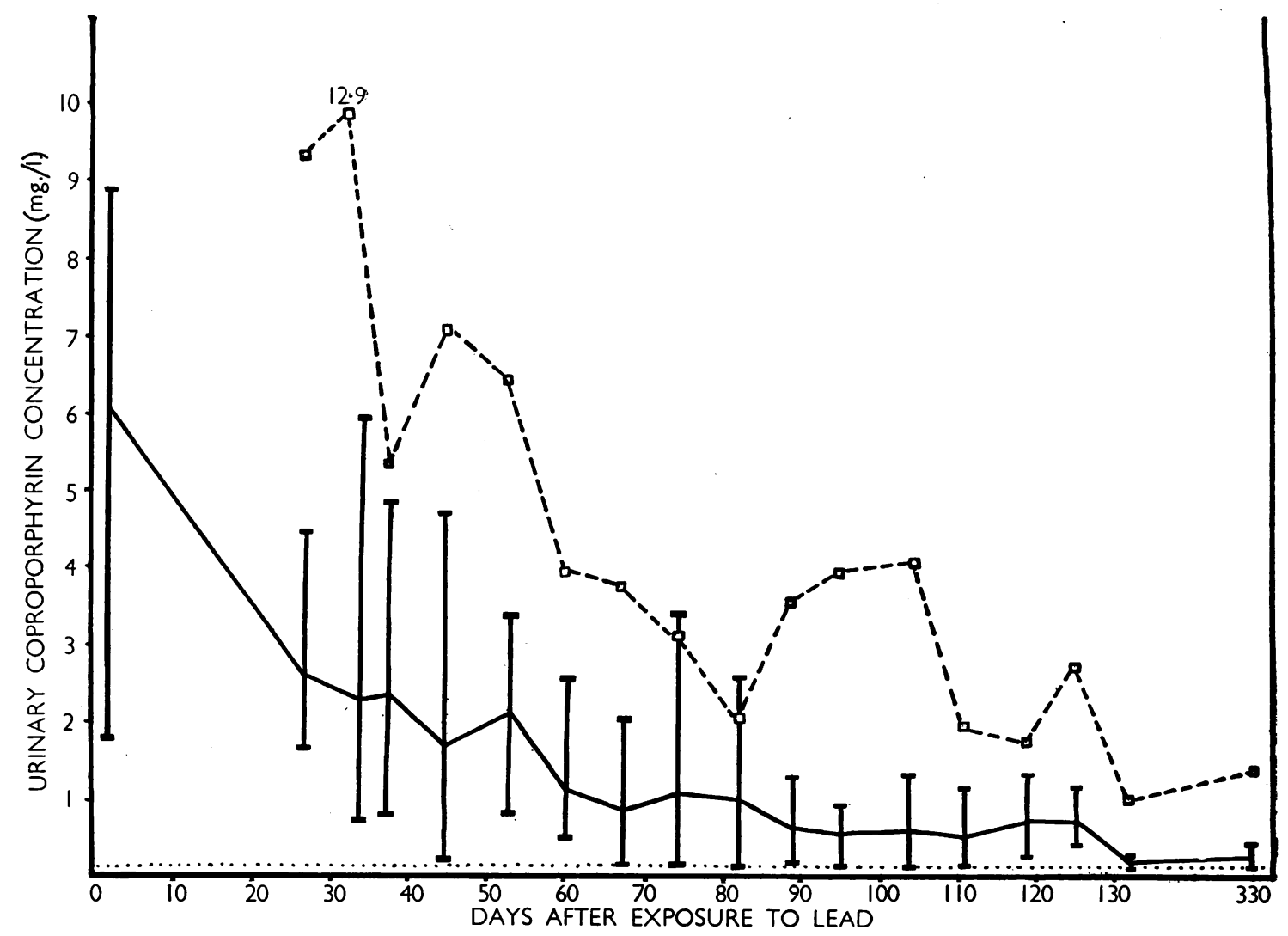

FIG. 4.-Graph showing changes in urinary coproporphyrin in lead poisoning. The upper curve is for the workman with protracted, heavy lead absorption (Case No. 4). The lower curve shows the means for the remaining six men. Vertical lines give the ranges of observations. The upper limit of normal is shown by the horizontal dotted line. 


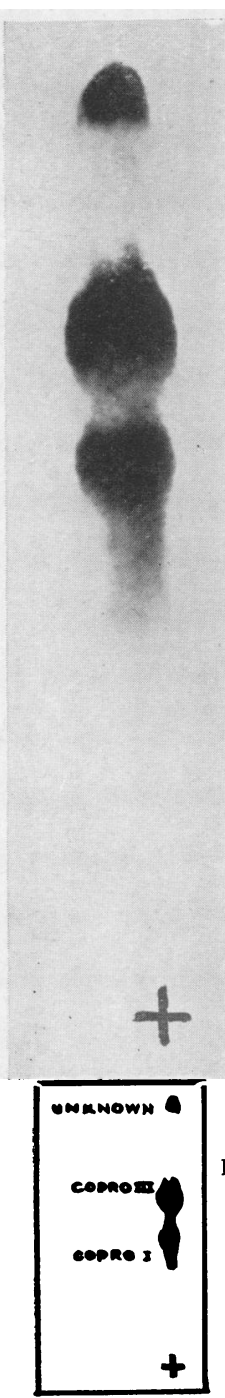

except in Case 3 whose low initial count remained unchanged. All counts after the 120th day were within the normal range of 1 to 3,000 (Lane, 1949).

Concurrently with improvement in the clinical condition and blood picture, the mean values of urinary lead and coproporphyrin concentrations reached normal limits at 55 and 133 days respectively (Figs. 3 and 4). One worker (Case 4), however, with a previous history of protracted, heavy lead absorption was excreting $1.4 \mathrm{mg}$. coproporphyrin per litre of urine 330 days after exposure. A temporary rise in porphyrin excretion at $\mathbf{1 1 0}$ days in four workmen was subsequently traced to their having done lead smelting without the knowledge of the works manager.

Single-dimensional chromatography (Nicholas and Rimington, 1949) of the pooled ethersoluble porphyrins collected during the first 130 days showed the presence of coproporphyrin

FIG. 5.-Chromatogram of porphyrin methyl esters prepared from urine in lead poisoning. Photograph of spots red-fluorescent in ultraviolet light. Solvent oleic acid-kerosene (1:1).
TABLE 2

URINARY COPROPORPHYRINS I AND III IN LEAD POISONING 330 DAYS AFTER EXPOSURE

\begin{tabular}{c|c|c|c}
\hline & \multicolumn{3}{|c|}{ Coproporphyrin I } \\
\cline { 2 - 3 } $\begin{array}{c}\text { Case } \\
\text { No. }\end{array}$ & Rf. & $\begin{array}{c}\text { Proportion in } \\
\text { Mixture } \\
(\%)\end{array}$ & $\begin{array}{c}\text { Urinary Concen- } \\
\text { tration } \\
(\mu \mathrm{g} . / 1 .)\end{array}$ \\
\hline 1 & 0.42 & 47 & 67 \\
2 & 0.44 & 40 & 42 \\
3 & 0.42 & 29 & 117 \\
$4^{*}$ & 0.41 & 20 & 348 \\
\hline & & Coproporphyrin III \\
\hline 1 & 0.64 & 53 & 76 \\
\hline 2 & 0.67 & 60 & 62 \\
\hline 3 & 0.69 & 71 & 285 \\
$4^{*}$ & 0.67 & 60 & 1045 \\
\hline
\end{tabular}

* This specimen also contained an unidentified porphyrin Rf.0.84 $20 \%$ of total porphyrin concentration. Data in this table are means of observations on urinary specimens collected on the 329th and 330th days.

only. Examination of the derived methyl esters by chromatography using oleic acid-kerosene 1 : 1 (Chu, Green, and Chu, 1951) showed that these comprised a mixture of coproporphyrin I $(30 \%)$ and coproporphyrin III $(70 \%)$.

Urinary specimens collected on the 329th and 330th days were examined (Figs. 5 and 6). Coproporphyrin I was present in each specimen, and ranged from $20-47 \%$ of the total porphyrin concentration (Table 2). It represented $28 \%$ of the pooled material.

Uroporphyrin was not detected in any of the ether-extracted residues.
Fig. 6.-Two-dimensional chromatogram of porphyrin methyl esters prepared from urine in lead poisoning. Photograph of spots red-fluorescent in ultra-violet light. Solvents chloroform-kerosene $(2 \cdot 6: 4)$ and n-propanol-kerosene $(1: 5)$.
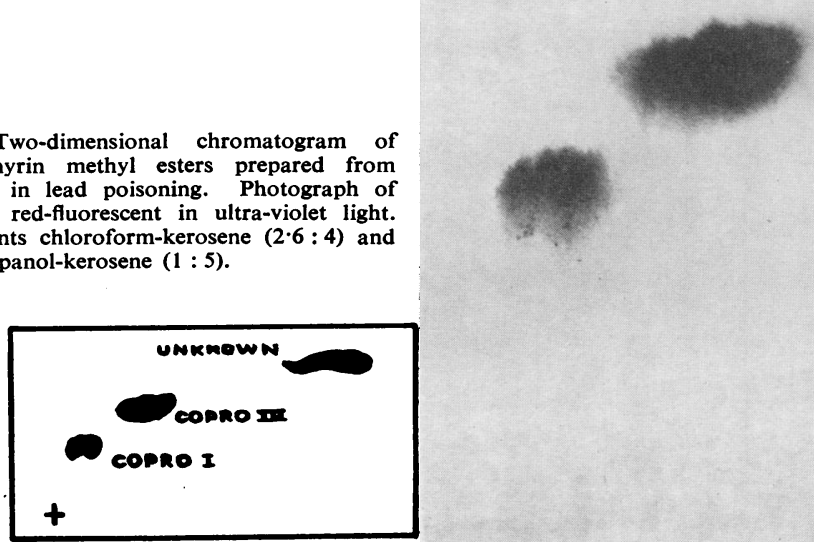
For comparison eight specimens of normal urine contained $38,37,28,90,71,17,17$, and $52 \mu \mathrm{g}$. per litre with a mean value of $44 \mu \mathrm{g}$. coproporphyrin per litre. On the Chu chromatogram coproporphyrin I constituted $55 \%$ of the total porphyrin.

\section{Discussion}

Forty-six litres of urine were collected during the first stage of the study, and contained $86.7 \mathrm{mg}$. ether-soluble porphyrins of which $30 \%$ was coproporphyrin I. If the coproporphyrin I had been normal it would have contributed only $1.6 \%$ of the total urinary porphyrin. As this result was entirely unexpected, further specimens were collected on the 329th and 330th days and these confirmed that an increase in total urinary porphyrin was accompanied by a rise in coproporphyrin I. We have calculated that when the bath enamellers had acute lead poisoning they were excreting approximately $1 \mathrm{mg}$. of coproporphyrin I per litre of urine, which, with the high punctate basophil count, is consistent with bone marrow hyperplasia. This hyperplasia would arise in response to an increased rate of breakdown of abnormal red blood cells, and, indeed, the workman with the heaviest lead absorption (No. 4) had a serum bilirubin level of $2 \mathrm{mg}$. per $100 \mathrm{ml}$. (indirect). However, it is evident that lead also interferes with haemoglobin production within the erythrocyte precursors, probably inhibiting many enzymes taking part in the synthesis of intermediates, including the formation of haem by incorporating iron into protoporphyrin 9. This disturbance of porphyrin metabolism leads to loss of coproporphyrin III in the urine.

Lead has, therefore, two toxic actions in haemopoiesis, which together are responsible for the anaemia. (1) It interferes with normal maturation of erythroid marrow cells leading to the production of so-called stippled cells which are rapidly broken down by the reticulo-endothelial system. (2) Haemoglobin synthesis in the precursor cells is inhibited, probably by a general action of lead on the enzymic formation of porphyrin and other intermediates.

Coproporphyrin I excretion appears to be associated with hyperplasia of the erythroid marrow cells in haemolytic jaundice, in congenital porphyria (Aldrich, Hawkinson, Grinstein, and Watson, 1951), and in lead poisoning, and is apparently independent of haemoglobin formation. It seems probable that the coproporphyrin isomers I and III arise by independent syntheses from their common precursor glycine. The possibility that coproporphyrin I may play a vital role in cell proliferation awaits further study.

This hypothesis is presented in an attempt to resolve the apparent anomalies of coproporphyrin I and III formation in lead poisoning, but it does not exclude the long recognized action of lead on the erythrocytes.

The practical issues involved in the use of urinary porphyrin excretion as an index of lead absorption will be discussed in a further communication.

\section{Summary}

A study has been made of urinary lead and coproporphyrin in seven cases of lead poisoning.

Accompanying the well recognized increased urinary excretion of coproporphyrin III in lead poisoning there was a concomitant increase of coproporphyrin I at a mean of $30 \%$ of the total porphyrin excretion.

It is suggested that coproporphyrins I and III are synthesized independently. Coproporphyrin I is associated with proliferation of marrow cells as distinct from coproporphyrin III, which is linked with the formation of haemoglobin within the cells.

We should like to thank Mr. S. Coxon and Mr. C. Howe for their valuable assistance in this work.

\section{REFERENCES}

Aldrich, R. A., Hawkinson, V., Grinstein, M., and Watson, C. J. (1951). Blood, 6, 685.

Aub, J. C., Fairhall, L. T., Minot, A. S., and Reznikoff, P. (1925). Medicine, Baltimore, 4, 1.

Chu, T. C., Green, A. A., and Chu, E. J. (1951). J. biol. Chem., 190, 643 .

Dobriner, K., and Rhoads, C. P. (1938). J. clin. Invest., 17, 105. Fischer, H., and Duesberg, R. (1932). Arch. exp. Path. Pharmak.,

166, 95.
Grinstein, M., Kamen, M. D., Wikoff, H. M., and Moore, C. V. (1950). J. biol. Chem., 182, 715.

Grotepass, W. (1932). Hoppe-Seyl. Z. physiol. Chem., 205, 193.

Kench, J. E. (1940). Biochem. J., 34, 1245.

, Gillam, A. E., and Lane, R. E.' (1942). Ibid., 36, 384

Lane, R. E. (1949). British Journal of Industrial Medicine, 6, 125. London, I. M., Shemin, D., and Rittenberg, D. (1948). J. clin. Invest., $27,547$.

Macfarlane, R. G., King, E. J., Wootton, I. D. P., and Gilchrist, M. (1948). Lancet, 1, 282.

McFadzean, A. J. S., and Davis, L. J. (1949). Quart. J. Med., 18,57 .

Nicholas, R. E. H., and Rimington, C. (1949). Scand. J. clin. Lab. Invest., 1,12 .

Rimington, C. (1936). Onderstepoort J. vet. Sci., 7, 567.

Rimington, C. (1936). Onderstepoort J. vet. Sci., 7, 567.
(1938). C. R. Lab. Carlsberg. Sér. Chim., 22, 454.

(1938). C. R. Lab. Carlsberg.

Watson, C. J. (1936). J., clin. Invest., 15, 327.

Watson, C. J. (1936). J. cl 